\title{
On the Original Igneous Source of Martian Fines
}

\author{
ALEX K. BAIRD \\ Department of Geology, Pomona College, Claremont, California 91711
}

AND

BENTON C. CLARK

Planetary Sciences Laboratory, Martin Marietta Aerospace, Denver, Colorado 80201

Received May 30, 1980; revised August 15, 1980

\begin{abstract}
The composition of the silicate portion of Martian regolith fines indicates derivation of the fines from mafic to ultramafic igneous rocks, probably rich in pyroxene. Rock types similar in chemical and mineralogical composition include terrestrial Archean basalts and certain achondrite meteorites. If these igneous rocks weathered nearly isochemically, the nontronitic clays proposed earlier as an analog to Martian fines could be formed. Flood basalts of pyroxenitic lavas may be widespread and characteristic of early volcanism on Mars, analogous to maria flood basalts on the Moon and early Precambrian basaltic komatiites on Earth. Compositional differences between lunar, terrestrial, and Martian flood basalts may be related to differences in planetary sizes and mantle compositions of the respective planetary objects.
\end{abstract}

\section{INTRODUCTION}

\section{(i) The Problem}

The Viking Lander spacecraft (the only direct probes of Mars' surface) were designed principally for life-detection experiments and imaging of the planetary surface at moderate resolution $(\Im 1 \mathrm{~cm}$ at best at $\sim 1$ $\mathrm{m})$. A miniaturized X-ray fluorescence spectrometer provided quantitative analyses for chemical elements heavier than sodium, but was limited to unprocessed samples of particle sizes under about $1 \mathrm{~cm}$; no rock drills, grinders, etc., were provided. Some limited additional chemical information on evolved gases was obtained on fines from gas chromatograph/mass spectrometer instruments. No instruments (such as X-ray diffraction, differential thermal analyzer, etc.) were included to provide direct mineralogical data, and Lander imagery was inadequate to unambiguously characterize petrologically the samples which were chemically analyzed or the numerous rocks in the immediate areas of the Landers. Indirectly, information on
Mars' surface mineralogy/petrology has been obtained from spectral reflectance studies of Lander imagery, Orbiter imagery, and Earth-based imagery. As discussed below, none of the reflectance studies gives wholly unique solutions and the problem remains to deduce a reasonable petrogenetic model to explain the chemical data in light of the other limited facts about Mars.

The point of this paper is not to dwell upon the present mineralogic nature of the fines which were chemically analyzed, but rather, to reassess a conclusion reached earlier (Baird et al., 1976; Toulmin et al., 1977), that the measured elemental abundances are unlike those of any known or plausible igneous materials-terrestrial, lunar, or meteoritic. That igneous activity extends back over a large part of Martian history is undoubted, with very abundant flood lavas in part predating the Tharsus shield volcanoes. In this paper we propose that the Viking-analyzed regolith fines provide some evidence of the compositional nature of this extensive igneous activity. 


\section{(ii) Earlier Interpretations}

The first mineralogic-petrologic interpretations of the elemental analyses of Martian surface materials took into account unusual abundance patterns (including high contents of sulfur and chlorine), the finegrained nature of the soil and the soil's magnetic properties, as well as results of reflectance spectra measurements and earlier deductions about the mineralogic character of Martian dust clouds by Hunt $e t$ al. (1973). It was concluded (Baird et al., 1976; Toulmin et al., 1977) that overall the properties best matched a model of Martian soil consisting principally of clay alteration products (smectites, including nontronite) with admixed salts and magnetic iron oxides. This interpretation, if correct, requires the interaction of relatively mafic magma or rock and large quantities of $\mathrm{H}_{2} \mathrm{O}$ for clay formation, presumably over a considerable time span. That abundant water has been important in the Martian past is supported by orbital imagery of major channels on the planetary surface; many authors have proposed abundant permafrost in the regolith, and some igneous structures (e.g., pedestal volcanoes; Olympus Mons) are suggested to have been erupted subglacially (Hodges and Moore, 1979).

The nontronite model was questioned by Gooding (1978), who argued, on thermodynamic grounds, that in the present Martian environment (considering $T-P_{\mathrm{O}_{2}}-P_{\mathrm{H}_{2} \mathrm{O}^{-}}$ $\boldsymbol{P}_{\mathrm{CO}_{2}}$ ), mafic minerals would be converted to oxides and carbonates, rather than clays. However, Gooding and Keil (1978) showed that, on the basis of thermodynamic calculations, favorable gas-solid weathering products of feldspar and mafic glasses, under present Martian conditions, could include metastable clays. Our doubts of the clay/salt, massive weathering model are more concerned with the geochemical balance between the proposed clays, a presumed basaltic source material, and the required vast (but apparently hidden) reser- voir of leftover components, such as Caand Al-bearing compounds. In this regard we note the uniqueness of identical results from two Lander sites $6000 \mathrm{~km}$ apart and the lack of substantive data bearing upon the reservoir question, although this may only be an expression of the lack of data regarding vertical heterogeneities in the Martian regolith.

Others (e.g., Evans and Adams, 1979; Evans et al., 1980) have shown that reflectance spectra from weathered Hawaiian tephra are reasonable matches to Martian Lander spectra even though the terrestrial material contains three times more alumina than that measured on Mars. In addition, certain synthetic gels of silica and iron hydroxide produce good spectral matches. It should be noted, however, that there is no evidence at either Lander site that the rocks are coated with weathering products (Moore et al., 1977).

That the Martian fines contain a highly magnetic mineral, about $1-7 \%$, has been well established by the Viking magneticproperties experiment (Hargraves et al., 1977). Although reddish in color, this material could be $\mathrm{Fe}_{3} \mathrm{O}_{4}$ grains with a very superficial coating of red oxide product(s) such as limonite, hematite, or maghemite. [As we concluded earlier (Clark et al., 1976), this coating must be thin on the much more abundant silicate grains in order to not totally absorb the X-ray emissions from light elements in those grains.] From study of the opaques in suspended dusts, Pollack et al. (1979) have inferred the presence of magnetite at about $2 \%$ by weight. Mafic igneous rocks typically contain magnetite, often titaniferous. We have found (Fig. 1) a sympathetic behavior of $\mathrm{Ti}$ and $\mathrm{Fe}$ concentrations in analyses of Martian fines and suggest that the silicate component could contain 2-5\% titaniferous magnetite with $\mathrm{TiO}_{2} / \mathrm{Fe}_{3} \mathrm{O}_{4}$ between 0.1 and 0.25 .

Huck et al. (1977) find the Lander camera spectral reflectance results to be consistent with iron-rich weathering products such as limonite and nontronite; Arvidson (per- 


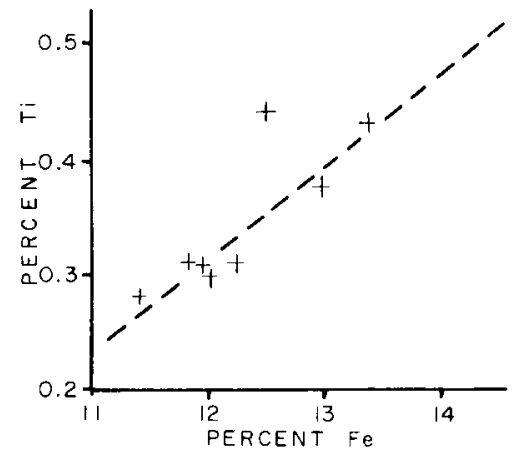

FIG. 1. Correlation of iron with titanium in Martian regolith fines from Planitia Utopia (preliminary values).

sonal communication) believes the spectra could not be used to eliminate pyroxene as a major constituent of the regolith fines.

Earth-based infrared spectra of dark areas of Mars have been interpreted as indicating orthopyroxene, clinopyroxene, and olivine (Huguenin et al., 1978). An area in Mare Acidalium produces spectral responses consistent with iron-rich calcic pyroxene (Huguenin et al., 1977). Maderazzo and Huguenin (1977) and McGetchin and Smyth (1978) have proposed models of alkaline picrite basalt for Martian lavas. Recent analysis by Singer (1979) of the highest-resolution spectrum yet achieved from a dark area, the Iapygia region, is interpreted as an oxide-stained mafic rock with principal absorption bands at $0.88 \mu \mathrm{m}$ (ferric oxide and/or orthopyroxene) and $0.99 \mu \mathrm{m}$ (clinopyroxene). As the instrumental techniques improve, the spectroscopic evidence for abundant olivine on Mars has apparently weakened and the upper limit for olivine at Iapygia is now estimated at $10 \%$, according to Singer (personal communication).

\section{EVALUATION METHODS}

\section{(i) Role of Volatiles}

Unless the Martian lithosphere is severely depleted in volatile elements (which the facts do not indicate) (Clark and Baird, $1979 a)$, the extensive volcanic eruptions of
Mars should have resulted in release of large quantities of reactive gases through time. As the present atmosphere contains mainly $\mathrm{CO}_{2}$ (and minor $\mathrm{H}_{2} \mathrm{O}$ ), the expected $\mathrm{Cl}$ - and S-bearing gases must have long since been chemically incorporated into the regolith. The extreme aridity of the Martian environment provides no escape for these water-soluble compounds. Thus, we and others have suggested that the measured contents of $\mathrm{S}, \mathrm{Cl}$, and $\mathrm{Br}$ (as well as unknown amounts of $\mathrm{H}_{2} \mathrm{O}$ and $\mathrm{CO}_{2}$ ) in fines may not be sedimentary leachates but, rather, may be accounted for by igneous activity (Clark and Baird, 1979a,b; Settle, 1979). However, these volatiles, probably ultimately derived from igneous activity, serve only to obscure the silicate nature of the regolith fines and are one cause of the difficulties encountered in deriving the composition of the original igneous component from the composition of the presentday Martian regolith.

\section{(ii) Silicate Analog Chemistry and Mineralogy}

In order to assess the possible nature and composition of the original silicate component of the Martian fines, we must ignore incorporated volatiles $\left(\mathrm{SO}_{2}, \mathrm{Cl}_{2}, \mathrm{Br}_{2}, \mathrm{H}_{2} \mathrm{O}\right.$, $\mathrm{CO}_{2}, \mathrm{O}_{2}, \mathrm{NO}_{x}$, etc.). We choose to do this by normalizing the sum of the principal oxides $\mathrm{SiO}_{2}, \mathrm{TiO}_{2}, \mathrm{Al}_{2} \mathrm{O}_{3}, \mathrm{FeO}, \mathrm{MgO}, \mathrm{CaO}$, $\mathrm{K}_{2} \mathrm{O}$, and $\mathrm{Na}_{2} \mathrm{O}$ (estimated) to $100 \%$. This composition (Table I) we term the "silicate fraction." The normative minerals derived from this composition (Table II) are principally iron-rich pyroxene and intermediate plagioclase, with ilmenite and minor quartz. To test how sensitive the bulk chemical composition might be to variations in the contents of pyroxene/plagioclase mixtures, the compositions of a comprehensive series of analogs were calculated from the theoretical compositions of albite, anorthite, diopside, hedenbergite, enstatite, and ferrosilite, plus magnetite and ilmenite. Four of the many 
TABLE I

Compositions of the Silicate Fraction of Martian Fines and Comparable Materials

\begin{tabular}{|c|c|c|c|c|c|}
\hline & \multicolumn{2}{|c|}{$\operatorname{Mars}^{a}$} & \multirow{2}{*}{$\begin{array}{l}\text { Ranges of } \\
\text { komatiitic } \\
\text { composition }^{b}\end{array}$} & \multirow{2}{*}{$\begin{array}{l}\text { Shergotty } \\
\text { meteorite }^{c}\end{array}$} & \multirow{2}{*}{$\begin{array}{c}\text { Kapoeta } \\
\text { meteorite }^{d}\end{array}$} \\
\hline & Nominal & Range & & & \\
\hline \multicolumn{6}{|c|}{ Oxide (wt \%) } \\
\hline $\mathrm{SiO}_{2}$ & 53.9 & $47-60$ & $44-54$ & 50.4 & 50.7 \\
\hline $\mathrm{TiO}_{2}$ & 1.0 & $0.6-1.5$ & $0-1$ & 0.8 & 0.4 \\
\hline $\mathrm{Al}_{2} \mathrm{O}_{3}$ & 6.8 & $5-9$ & $3-15$ & 6.9 & 8.3 \\
\hline $\mathrm{FeO}$ & 19.7 & $16-23$ & $9-13$ & 19.1 & 16.3 \\
\hline $\mathrm{MgO}$ & 10.0 & $5-15$ & $6-38$ & 9.3 & 16.1 \\
\hline $\mathrm{CaO}$ & 6.7 & $5-8$ & $3-13$ & 10.1 & 6.6 \\
\hline $\mathrm{Na}_{2} \mathrm{O}$ & $(1.6)$ & $0-4$ & $0-4$ & 1.4 & 0.3 \\
\hline $\mathrm{K}_{2} \mathrm{O}$ & 0.1 & $\begin{array}{ll}0- & 0.3\end{array}$ & $0-2$ & 0.2 & 0.0 \\
\hline \multicolumn{6}{|c|}{ Trace elements (ppm) } \\
\hline $\mathrm{Sr}$ & 95 & $55-135$ & $6-160$ & $50^{e}$ & - \\
\hline $\mathrm{Y}$ & 70 & $35-105$ & $4-19$ & $19 c$ & - \\
\hline $\mathrm{Zr}$ & 35 & $10-60$ & $9-44$ & $41^{c}$ & - \\
\hline
\end{tabular}

${ }^{a}$ Clark et al. (1976). Major oxides normalized to $100 \%$, assuming $\mathrm{Na}_{2} \mathrm{O}$ value indicated and ignoring minor components such as $\mathrm{MnO}_{2}, \mathrm{P}_{2} \mathrm{O}_{5}$, etc.; traces are averages of first analyses at two Lander sites.

${ }^{b}$ Nesbitt et al. (1979), Table I.

c Duke (1968).

${ }^{d}$ Simpson and Ahrens (1977).

e Nyquist et al. (1979b) and Nyquist, personal communication.

models calculated, encompassing much of the allowable range of Martian values, are given in Table II (normative mineralogy) and Table III (chemistry). It is evident (Fig. 2) that relatively large variations in the amounts of the major minerals (pyroxenes, feldspars) still yield analog mixtures of chemical compositions within the estimated compositional limits of the proposed silicate fraction of Martian fines. The relatively simple mineralogical compositions given consider only end-member plagioclases, $\mathrm{Fe}$ and $\mathrm{Mg}$ end-member ortho- and clino-pyroxenes, and $\mathrm{Fe}$ and $\mathrm{Ti}$ oxides. Though it is possible that other mineral mixtures could be found which would equally well fit the composition of Martian fines, we believe the excellence of fit derived from these uncomplicated, petrologically realistic cases lends credence to the mineralogic suite selected. Furthermore it is important that the models embrace large variations in chemistry $\left(5-9 \% \quad \mathrm{Al}_{2} \mathrm{O}_{3}, 9\right.$
$14 \% \mathrm{MgO}, 6-8 \% \mathrm{CaO}$ ) without altering the overall mineralogic (mainly pyroxeneplagioclase-magnetite) conclusions.

All analog models, when cast in CIPW

TABLE II

CIPW Normative Mineralogy of the Nominal Mars Fines Silicate Fraction and Permitted Analogs (Weight Percent)

\begin{tabular}{lccccc}
\hline \multirow{2}{*}{ Mineral } & Mars & \multicolumn{4}{c}{ Analog } \\
\cline { 3 - 6 } & & A & B & C & D \\
\hline Quartz & 4 & 0 & 0 & 0 & 0.4 \\
Plagioclase & 25 & 16.3 & 25.8 & 26.5 & 27.8 \\
$\quad$ Anorthite \% & 45 & 57 & 53 & 59 & 69 \\
Diopside & 19 & 25.7 & 15.9 & 17.0 & 17.2 \\
Hypersthene & 50 & 53.3 & 49.8 & 52.6 & 50.8 \\
$\quad$ Enstatite \% & 42 & 53 & 49 & 46 & 39 \\
Olivine & 0 & 1.1 & 4.6 & 0.1 & 0 \\
$\quad$ Forsterite $\%$ & & 50 & 47 & 44 & \\
Magnetite & 0 & 2.2 & 2.4 & 2.3 & 2.6 \\
Ilmenite & 1.9 & 1.2 & 2.1 & 1.4 & 1.2 \\
\hline
\end{tabular}


TABLE III

Chemical Composition of Silicate Analogs to Nominal Martian fines (Weight Percent)

\begin{tabular}{lrrrr}
\hline \multirow{2}{*}{ Oxides } & \multicolumn{5}{c}{ Analog } \\
\cline { 2 - 5 } & \multicolumn{1}{c}{$\mathrm{A}$} & \multicolumn{1}{c}{$\mathrm{B}$} & \multicolumn{1}{c}{$\mathrm{C}$} & $\mathrm{D}$ \\
\hline $\mathrm{SiO}_{2}$ & 51.0 & 49.9 & 50.5 & 49.3 \\
$\mathrm{TiO}_{2}$ & 0.6 & 1.1 & 0.7 & 0.6 \\
$\mathrm{Al}_{2} \mathrm{O}_{3}$ & 4.8 & 7.4 & 7.8 & 8.7 \\
$\mathrm{FeO}$ & 19.9 & 20.9 & 20.6 & 22.9 \\
$\mathrm{MgO}$ & 14.3 & 12.5 & 11.5 & 9.2 \\
$\mathrm{CaO}$ & 8.2 & 6.4 & 7.3 & 8.0 \\
$\mathrm{Na}_{2} \mathrm{O}$ & 0.9 & 1.4 & 1.3 & 1.0 \\
$\mathrm{~K}_{2} \mathrm{O}$ & 0.6 & 1.1 & 0.7 & 0.6 \\
\hline
\end{tabular}

normative mineralogy (Table II) are about one-half orthopyroxene, one-quarter clinopyroxene, and one-quarter labradorite feldspar, and are either slightly quartz normative or slightly olivine normative. The remainder can be interpreted as a few percent magnetite (calculations assumed $\mathrm{Fe}^{2+} / \mathrm{Fe}^{3+}=0.93$ ), possibly titaniferous. Their norms are clearly and unambiguously interpretable as typical, if not terrestrially common, mafite or ultramafite such as melanobasalt (ankaramite)/melanogabbro or pyroxenite families of rocks. Rocks corresponding to these mineral compositions are distinctly olivine-poor compared to the alkaline picrite basalt compositions proposed for Martian lavas by Maderazzo and $\mathrm{Hu}-$ guenin (1977) and McGetchin and Smyth (1978). The high pyroxene content, however, is consistent with Viking Lander and Earth-based imagery in the visible and near infrared as noted above. This agreement could, of course, be totally fortuitous if the Martian fines were produced by processes of strongly nonisochemical weathering (see Gooding, 1980, for discussion). We believe a complete range of (unfortunately) unassessable possibilities exists for the origin(s) of the fines ranging from totally nonisochemical to mainly isochemical. The speculation to follow is based upon the latter possibility.

\section{MARTIAN IGNEOUS ROCKS}

\section{(i) Source Magmas and Komatiitic Volcanism}

Most models of the Martian mantle (Lewis, 1972; McGetchin and Smyth, 1978; Johnston and Toksoz, 1977; Goettel, 1978; Morgan and Anders, 1979) show distinctly lower $\mathrm{MgO}$, much higher $\mathrm{FeO}$, and, thus, higher density than the Ringwood (1975) model for Earth's mantle. Assuming a mantle source for volcanic magma, McGetchin and Smyth (1978) derive a picritic partial melt; we are suggesting a pyroxenitic partial melt. The lack of constraints on the nature of this melting (e.g., pressure, temperature, extent, and parent composition including water, carbon dioxide, sulfur, and other volatiles), and the nature of subsequent melt differentiation, makes clear-cut petrologic distinctions impossible. However, it is encouraging to note that the independent reasoning of both McGetchin and Smyth and ourselves points to very mafic to ultramafic igneous activity on Mars.

Viljoen and Viljoen (1969a) proposed a new class of ultramafic igneous rocks, komatiites, as chemically distinctive members of early Precambrian greenstone belts in Africa, and numerous subsequent workers

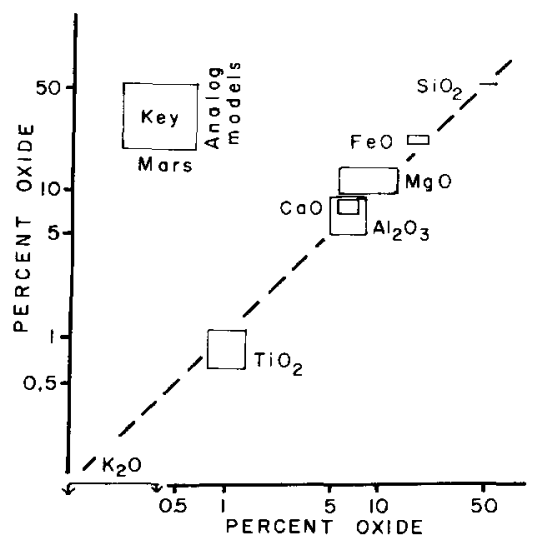

FIG. 2. Comparison of chemical composition of Martian regolith fines and analog models. Values plotted are weight percent oxide from Tables I and III. 

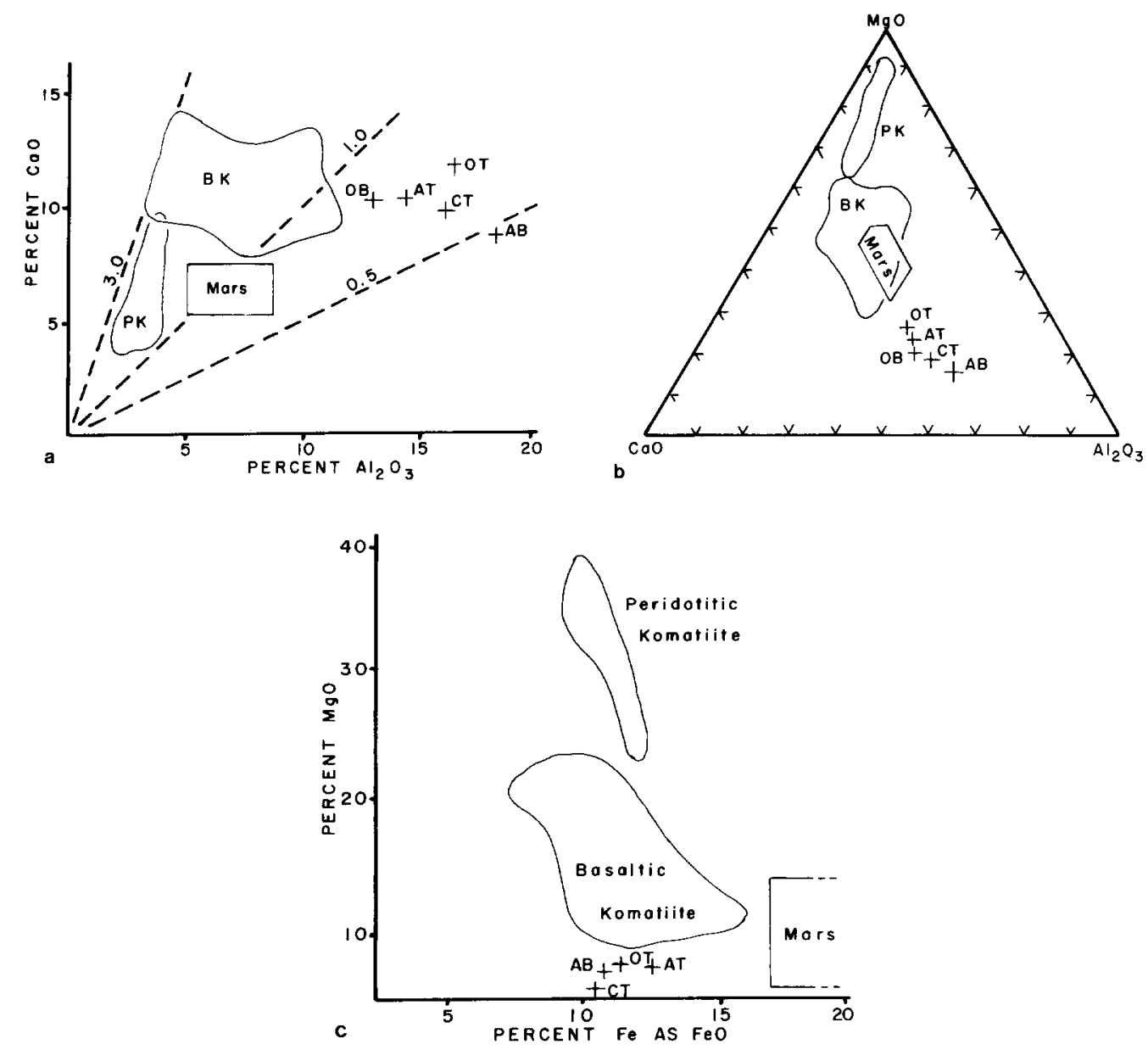

FIG. 3. Comparison of chemical compositions of komatiitic rocks, other terrestrial basaltic rocks, and the composition of the silicate nominal silicate portion of Martian fines. $\mathrm{PK}=$ peridotitic komatiite; $\mathrm{BK}=$ basaltic komatiite; OT = average oceanic tholeiite; $\mathrm{CT}=$ average continental tholeiite; $\mathrm{AB}=$ average alkali basalt; $\mathrm{OB}=$ average olivine basalt; and $\mathrm{AT}=$ average Archaean tholeiite. In Part a, dashed lines are $\mathrm{CaO} / \mathrm{Al}_{2} \mathrm{O}_{3}$ ratios. Figure modified from Viljoen and Viljoen (1969a) with Martian data added.

(e.g., Williams, 1972; Arndt et al., 1977; Viswanathan, 1974; Naqvi, 1979) have recognized these rocks in other continental interiors. Though mostly strongly deformed and metamorphosed, preserved textures and structures show that these rocks were lava flows. Viljoen and Viljoen (1969b) recognized peridotitic and basaltic subgroups of komatiites and believed that the former subgroup represented very closely the composition of the primitive Earth mantle. Brooks and Hart (1972) searched geochemical data bases of more than 20,000 analyses in an effort to test the uniqueness of koma- tiitic compositions and found that these rocks are very rare outside of Precambrian terranes. They further suggested that although certain cumulate rocks mimicked komatiite compositions (and therefore textural criteria were important for separating true members of the group), the chemical criteria for distinguishing basaltic komatiites are: $\mathrm{SiO}_{2}, 45-53 \% ; \mathrm{CaO} / \mathrm{Al}_{2} \mathrm{O}_{3}$, greater than $1.0 ; \mathrm{K}_{2} \mathrm{O}$, less than $0.9 \%$, usually less than $0.5 \%$; $\mathrm{TiO}_{2}$, less than $0.9 \%$; and $\mathrm{MgO}$, greater than $9.0 \%$. Nesbitt et al. (1979) think most komatiites have $\mathrm{CaO} / \mathrm{Al}_{2} \mathrm{O}_{3}$, about 1.0 , instead of higher. 
That the composition of Martian fines conforms to these chemical criteria is evident from Table I and Fig. 3. However, the more that is learned about komatiites the more complicated the distinction becomes between them and other high-MgO basalts (see Nesbitt et al., 1979, for a detailed discussion). Arndt et al. (1977) proposed basaltic komatiite (under $12 \% \mathrm{MgO}$ ), pyroxenitic komatiite (12-20\% $\mathrm{MgO})$, and peridotitic komatiite (more than 20\% MgO). Naldrett and Turner (1977) suggest magnesian basalt (10-12\% MgO), pyroxenite (12-20\% $\mathrm{MgO})$, pyroxene peridotite $(20-30 \% \mathrm{MgO})$, and peridotite or peridotitic komatiite (more than $30 \% \mathrm{MgO}$ ).

Despite problems of definition and description of komatiitic rocks, it seems clear (Fig. 3) that the Martian fines data show chemical patterns similar to those of komatiitic rocks and dissimilar to those of other terrestrial basalts, except in the ratio of $\mathrm{FeO} / \mathrm{MgO}$ where the Martian data are dissimilar to the data for all terrestrial basalts (Fig. 3c). This comparison cannot (and probably should not) be pressed in great detail for at least two reasons: (1) komatiites are extremely variable in chemical composition; and (2) it is unknown how closely the composition of Martian fines represents that of igneous rock on Mars. Martian values for $\mathrm{MgO}$ fall within the lower range (Nesbitt et al., 1979, Table I) of $\mathrm{MgO}$ for komatiites $(6.4-37.8 \%)$, but the highest equivalent $\mathrm{FeO}$ value reported for komatiites is $6 \%$ lower than the value for Martian fines. This is the single major discrepancy in comparing the Martian and komatiitic chemistries. We find it intriguing, therefore, that all models of Martian magma source material involve higher iron and lower magnesium than analogous source material for Earth.

\section{(ii) Meteorites: Igneous Analogs to Martian Mineralogy}

Shergottites are achondritic meteorites composed of pyroxene and maskelynite (shock-transformed plagioclase glass) (Duke, 1968; Stolper and McSween, 1979). The compositional similarities to Martian fines are shown in Table I; only $\mathrm{CaO}$ falls outside the permissible range of major oxides. The normative mineralogy of shergottites is, of course, in excellent agreement with their modal mineralogy in amount of plagioclase, anorthite content of plagioclase, total pyroxene, and magnetite content, but shergottite pyroxene is all monoclinic (pigeonite and augite), whereas the shergottite norms and the analog model norms generate a large portion of orthopyroxene (because norms assume equilibrium conditions). Furthermore, the Shergotty meteorite contains $2 \%$ titanomagnetite with $\mathrm{TiO}_{2} / \mathrm{Fe}_{3} \mathrm{O}_{4}=0.22$ (Stolper and McSween, 1979). These chemical and derived mineralogical compositions of Martian fines and shergottites are strikingly similar.

Similarly, we draw attention to another meteorite group, the howardites and, specifically, the meteorite Kapoeta that is similar in composition (Table I) to the Martian regolith fines. Howardites are apparently lithified meteorite parent-body regolith and consist of a mechanical mixture of eucrites (basaltic achondrites) and diogenites (orthopyroxenites) (McCarthy et al., 1973; Middlefehldt, 1979). The compositional similarities are considerable, with the only discrepancies the higher $\mathrm{MgO}$ and the slightly lower $\mathrm{FeO}$ in Kapoeta.

We do not propose any genetic relationships between these meteorites and Mars, ${ }^{1}$

\footnotetext{
${ }^{1}$ The possibility of a genetic connection between Mars and shergottites has been suggested (Walker et al., 1979; McSween et al., 1979). Nyquist et al. (1979a) have recently concluded that the igneous formation of shergottites occurred only $650 \mathrm{my}$ B.P. As pointed out by Stolper and McSween (1979), such a young age presents problems in deriving these meteorites from small bodies in the solar system; only the larger planets would have radioactively generated igneous activity to form these apparent cumulates this late in the history of the system. If the dynamic difficulties of deriving meteorites from large bodies with high escape velocities (Wetherill, 1974) could be explained and if such mechanism could encompass escape without total melting of the ejected objects, perhaps a Martian origin (Nyquist et al., 1979b) for shergottites could be seriously entertained. Indeed, Wasson and Wetherill (1979) go so far as to state, "If any meteorite came from Mars, Shergotty seems the best candidate."
} 
except that they are further examples of igneous material similar in composition to the Martian regolith fines. Thus, elsewhere in the solar system, igneous rocks similar in composition to the possible source rocks of Martian fines have formed, possibly under similar physicochemical conditions. Additional credence is thus given to the model that Martian source materials were igneous, mafic rocks.

\section{(iii) Ultrabasic Lunar Glass}

Heiken et al. (1974) have described highiron and relatively low alumina glasses from Apollo 11, 15, and 17 sites which they interpret as being igneous, not impact, in origin. Bunch et al. (1972) have analyzed other glasses from the Apollo 12 site and present norms which are dominated by pyroxenes and calcic plagioclase. None of the analyzed lunar glasses are ideal matches to the composition of Martian fines (generally too high in $\mathrm{Al}_{2} \mathrm{O}_{3}, \mathrm{MgO}$, and/or $\mathrm{TiO}_{2}$ and too low in $\mathrm{FeO} / \mathrm{MgO}$ compared to Mars). But they are further examples of the occurrence of highly mafic volcanism in the solar system.

\section{MARTIAN FINES: LIMITING MODELS}

With the present level of understanding of the composition and physical properties of Martian surface materials (and the lack of direct mineralogical data), there seem to be four limiting cases for speculations on the makeup of the fine regolith on Mars:

(1) Derived directly and mainly isochemically from very mafic to ultramafic igneous rocks, similar to terrestrial Precambrian basaltic rocks, whose parent magma was derived by partial melting of a mantle higher in $\mathrm{FeO}$ and density than that of Earth (arguments in this paper; McGetchin and Smyth, 1978).

(2) Mechanical mixture of material derived from distinct igneous rocks. For example, the mixture may consist of basaltic and ultramafic rock derivations (Clark and Baird, 1979b) or material akin to eucrite and diogenite-like sources (howardite comparison, this paper).

(3) Weathering products (perhaps nontronitic) totally derived (Baird et al., 1976) or partially derived (Maderazzo and $\mathrm{Hu}$ guenin, 1977) from mafic material(s) above, partially or totally broken down to simple oxides and carbonates (Gooding, 1978; Gooding and Keil, 1978).

(4) Products of nonisochemical weathering, formed by some process which concentrated a residuum more mafic than the original source material (for example, palogonite weathering product of basaltic glass; Allen et al., 1980).

All cases include a secondary, near-surface enrichment of $\mathrm{S}, \mathrm{Cl}$, and $\mathrm{Br}$, but in cases (1) and (2) these elements might be added volcanogenetically in the gas phase whereas in cases (3) and (4) they would be supplied as efflorescent salts from upwardly percolating leachates. These are extreme limiting cases, but do not preclude derivation of the fines by overall processes combining both igneous activity and weathering, the latter either totally or partially isochemical.

\section{DISCUSSION AND CONCLUSIONS}

Each of the limiting models for the origins of the silicate portion of Martian regolith fines can be evaluated for reasonableness in light of other geologic knowledge about Mars, and in light of geochemical principles. There are no data to support the existence of mafic-poor surface materials over a major portion of the planet; further, a major concentration of mafic residua during weathering of such materials seems improbable. Without direct mineralogic information, however, none of the models can be firmly excluded. The composition of the silicate portion of Martian fines shows many affinities to the compositional patterns of igneous, pyroxene-rich rock families, including certain meteorites. Pyroxene-rich lavas would be excellent parental material to interact with $\mathrm{H}_{2} \mathrm{O}$ to 
produce nontronitic clays, since the alteration can be nearly isochemical. Thus, in our limiting models case (3) is not mutually exclusive of cases (1) and (2): fines could be pulverized igneous rock, or clay alteration of igneous material, or both. A mineralogic composition dominated by pyroxenes and/or nontronitic clay is compatible with spectral reflectance studies of Mars.

We further speculate that the lavas from which the fines were derived could have been iron-rich komatiite-like basalts. These lavas may be the dominant rock type over much of Mars. Their high iron/magnesium ratio can be explained by derivation from a Martian mantle enriched in iron and depleted in magnesium, compared to Earth's mantle. Such lavas would be very fluid (Bottinga and Weill, 1972), a property consistent with the enormous distances individual flows can be traced in orbital imagery (Carr et al., 1977) and consistent with proposals that some Martian channels could have been eroded by flowing lava (Cutts et al., 1978; Blasius and Cutts, 1981).

Though there is no unanimity on ages of Martian surface features (Soderblom et al., 1974; Neukum and Wise, 1976) it seems apparent that large-scale flood eruptions and volcanic plains formation are relatively old, perhaps in excess of $\sim 3.2 \mathrm{by}$, in contrast to the building of shield volcanic constructs such as Olympus Mons and other volcanoes on the Tharsis ridge. Green (1972) has suggested that terrestrial komatiite formation was coeval with the formation of lunar maria and was, therefore, in excess of 3.2 by B.P. On three planetary bodies (Mercury may be a fourth) evidence of extensive Archean basaltic flooding is preserved; on each planet the differences in composition of the flood basalts might be correlated with differences known or suspected in their internal structure and composition. It seems that the Moon and Mercury remain arrested in an early Precambrian state. Mars has developed shield volcanism, but no highly evolved igneous products, such as those on Earth.
These planetary differences seem understandable in terms of relative overall size of planets and their relative core sizes.

\section{ACKNOWLEDGMENTS}

We thank H. Y. McSween, Jr., for pointing out to us the correspondence of shergottite chemical compositions to that of Martian fines, and McSween, F. Fanale, A. O. Woodford, K. Keil, and J. L. Gooding for reviews of an earlier version of the paper. In addition, Gooding served as a formal reviewer of this paper for Icarus and provided helpful references on lunar glasses. This work was supported in part by the Mars Data Analysis Program, Grant NSG-7566 (Baird) and Contract NASW-3284 (Clark).

Note added in proof. Our calculation of the nominal composition of the silicate component of Martian fines (column II, Table I) was published earlier without our knowledge by McSween and Stolper (1980).

\section{REFERENCES}

Allen, C. C., Gooding, J. L., And Keil, K. (1980). Partially weathered basaltic glass-A Martian soil analog. Lunar Planet. Sci. Conf. XI, 12-14 (abstract).

Arndt, N. T., Naldrett, A. J., And Pyke, D. R. (1977). Komatiitic and iron-rich tholeiitic lavas of Munro Township, northeast Ontario. J. Petrol. 18, $319-369$.

Baird, A. K., Toulmin, P., III, Clark, B. C., Rose, H. J., Jr., Keil, K., Christian, R. P., AND GoodING, J. L. (1976). Mineralogic and petrologic implications of Viking geochemical results from Mars: Interim results. Science 194, 1288-1293.

Blasıus, K. L., AND CuTts, J. A. (1981). Rille-like valleys of western Chryse Planitia, Mars: A lava erosion hypothesis for their origin. Icarus, in press.

Bottinga, Y., And Weill, D. F. (1972). The viscosity of magmatic silicate liquids: A model for calculation. Amer. J. Sci. 272, 438-475.

Brooks, C., AND HART, S. R. (1972). On the significance of komatiite. Geology 2, 107-110.

Bunch, T. E., Prinz, M., AND Keil, K. (1972). Electron microprobe analyses of lithic fragments and glasses from Apollo 12 lunar samples. Spec. Pub. No. 4, Univ. New Mexico Inst. of Meteoritics, 1-14.

Carr, M. H., Greeley, R., Blasius, K. R., Guest, J. E., ANd Murray, J. B. (1977). Some Martian volcanic features as viewed from the Viking Orbiters. J. Geophys. Res. 82, 3985-4015.

Clark, B. C., ANd Baird, A. K. (1979a). Volatiles in the Martian regolith. Geophys. Res. Lett. 6, 811814.

Clark, B. C., and Baird, A. K. (1979b). Is the 
Martian lithosphere sulfur rich? J. Geophys. Res. 84, 8395-8403.

Clark, B. C., III, Baird, A. K., Rose, H. J., JR., Toulmin, P., III, Keil, K., Castro, A. J., Kelliher, W. C., Rowe, C. D., And Evans, P. H. (1976). Inorganic analyses of Martian surface samples at the Viking Lander sites. Science 194, 12831288.

Cutts, J. A., Roberts, W. H., and Blasius, K. L. (1978). Martian channels formed by lava erosion. Lunar Planet. Sci. Conf. IX, 209 (abstract).

DukE, M. B. (1968). The Shergotty meteorite: Magmatic and shock metamorphic features. In Shock Metamorphism of Natural Materials (B. M. French and N. M. Short, Eds.) pp. 613-621. Mono Book Corp., Baltimore, Md.

Evans, D. L., And Adams, J. B. (1979). Comparison of Viking Lander multispectral images and laboratory reflectance spectra of terrestrial samples. Proc. Lunar Planet. Sci. Conf. 10th, 370-372.

Evans, D. L., Adams, J. B., and Wenner, D. B. (1980). Amorphous gels as possible analogs to Martian weathering products. Lunar Planet. Sci. Conf. $X I, 271-272$ (abstract).

Goettel, K. A. (1978). The composition of Mars. NASA Technical Memorandum 79729, 116-117.

Gooding, J. L. (1978). Chemical weathering on Mars: Thermodynamic stabilities of primary minerals (and their alteration products) from mafic rocks. Icarus 33, 483-513.

Gooding, J. L. (1980). Geochemical fractionations during the evolutions of Martian soils. Lunar Planet. Sci. Conf. XI, 342-344 (abstract).

Gooding, J. L., AND KeIL, K. (1978). Alteration of glass as a possible source of clay minerals on Mars. Geophys. Res. Lett. 5, 727-730.

GrEeN, D. H. (1972). Archean greenstone belts may include terrestrial equivalents of lunar maria? Earth Planet. Sci. Lett. 15, 263-270.

Hargraves, R. B., Collison, D. W., Arvidson, R. E., AND SPITZER, C. R. (1977). The Viking magnetic properties experiment: Primary Mission results. $J$. Geophys. Res. 82, 4547-4558.

Heiken, G. H., McKay, D. S., and Brown, R. W. (1974). Lunar deposits of possible pyroclastic origin. Geochim. Cosmochim. Acta 38, 1703-1718.

Hodges, C. A., And Moore, H. J. (1979). The subglacial birth of Olympus Mons and its aureoles. J. Geophys. Res. 84, 8061-8074.

Huck, F. O., Jobson, D. J., Park, S. K., Wall, S. D., Arvidson, R. E., Patterson, W. R., AND Benton, W. D. (1977). Spectrophotometric and color estimates of the Viking Lander sites. $J$. Geophys. Res. 82, 4401-4411.

Huguenin, R. L., Adams, J., and McCord, T. B. (1977). Mars: Surface mineralogy from reflectance spectra. Lunar Planet. Sci. Conf. VIII, 478-480.

Huguenin, R. L., Head, J. W., And McGetchin, T.
R. (1978). Petrologic units in Margaritifer Sinus and Coprates quadrangles. NASA Technical Memorandum 79729, 118-120.

Hunt, G. R., Logan, L. M., and Salisbury, J. H. (1973). Mars: Components of infrared spectra and the composition of the dust cloud. Icarus 18, 459469.

Johnston, D. H., AND Toksoz, N. M. (1977). Internal structure and properties of Mars. Icarus 32, 7384.

LEWIS, J. S. (1972). Metal/silicate fractionation in the Solar system. Earth Planet. Sci. Lett. 15, 286-290.

Maderazzo, M., and Huguenin, R. L. (1977). Petrologic interpretation of Viking XRF analysis based on reflection spectra and the photochemical weathering model. Bull. Amer. Astron. Soc. 9, 527 528.

McCarthy, T. S., Erlank, A. J., And Willis, J. P. (1973). On the origin of eucrites and diogenites. Earth Planet. Sci. Lett. 18, 433-442.

McGetchin, T. R., And Smyth, J. R. (1978). The mantle of Mars: Some possible geological implications of its high density. Icarus 34, 512-536.

McSween, H. Y., AND StolPer, E. M. (1980). Basaltic meteorites. Sci. American 242, 54-63.

McSween, H. Y., Stolper, E. M., TAYlor, L. A., Muntean, R. A., O’Kelley, G. D., Eldridge, J. S., Biswas, S., NGo, H. T., and Lipschutz, M. E. (1981). Petrogenetic relationship between Allan Hills 77005 and other achondrites. Earth Planet. Sci. Lett., in press.

Middlefehldt, D. W. (1979). Petrographic and chemical characterization of igneous lithic clasts from mesosiderites and howardites and comparison with eucrites and diogenites. Geochim. Cosmochim. Acta 43, 1917-1935.

Moore, H. J., Hutton, R. E., Scott, R. F., SPItZER, C. R., AND Shorthill, R. W. (1977). Surface materials of the Viking Lander sites. J. Geophys. Res. 82, 4497-4523.

Morgan, J. W., And Anders, E. (1979). The chemical composition of Mars. Geochim. Cosmochim. Acta 43, 1601-1610.

NaldretT, A. J., And Turner, A. R. (1977). The geology and petrogenesis of a greenstone belt and related nickel sulfide mineralization of Yakabindie, Western Australia. Precambrian Res. 5, 43-103.

NAqVI, S. M. (1979). Distribution of elements in the crust and mantle during the Archaean: Evidence from the Indian Shield. Chem. Geol. 24, 1-23.

Nesbitt, R. W., Sun, S. S., and Purvis, A. C. (1979). Komatiites: Geochemistry and genesis. Canad. Mineral. 17, 165-186.

Neukum, G., AND WISE, D. (1976). Mars: A standard curve and a possible new time scale. Science 194, 1381-1387.

Nyquist, L., WoOden, J., Bansal, B., WeismanN, H., MCKAY, G., AND Bogard, D. (1979a). Rb-Sr 
ages of the Shergotty achondrite and implications for metamorphic resetting of isochron ages. Geochim. Cosmochim. Acta 43, 1057-1074.

Nyquist, L., Wooden, J. L., Weismann, H., Shih, C. -Y., BANSAL, B. M., MCKay, G., AND Bogard, D. D. (1979b). Early differentiation, late magmatism, and Recent bombardment of the Shergottite parent planet. 42nd Annual Meeting, Meteoritical Society, Heidleberg (abstract).

Pollack, J. B., Colburn, D. S., Flaser, F. M., Kahn, R., Carlston, C. E., and Pidek, D. (1979). Properties and effects of dust particles suspended in the Martian atmosphere. J. Geophys. Res. 84, 2929 2945.

Ringwood, A. E. (1975). Composition and Petrology of the Earth's Mantle. McGraw-Hill, New York.

Settle, M. (1979). Formation and deposition of volcanic sulfate aerosols on Mars. J. Geophys. Res. 84, 8343-8354.

Simpson, A. B., ANd Ahrens, L. H. (1977). The chemical relationship between howardites and the silicate fraction of mesosiderites. In Comets, Asteroids and Meteorites (A. H. Delsemme, Ed.). Univ. of Toledo Press, Toledo, Ohio.

Singer, R. B. (1979). Mars: Petrologic analysis of near-infrared spectra of dark regions. Bull. Amer. Astron. Soc. 11, 574 (abstract).

Soderblom, L. A., Condit, C. D., West, R. A., Herman, B. M., and Kreidler, T. J. (1974). Martian planetwide crater distributions: Implications for geologic history and surface processes. Icarus 22, 239-263.

Stolper, E. M., AND McSween, H. Y., JR. (1979). Petrology and origin of the shergottite meteorites. Geochim. Cosmochim. Acta 43, 1475-1498.
Toulmin, P., III, Baird, A. K., Clark, B. C., Keil, K., Rose, H. J., JR., Christian, R. P., Evans, P. H., ANd Kelliher, W. C. (1977). Geochemical and mineralogical interpretation of the Viking inorganic chemical results. J. Geophys. Res. 82, 4625-4634.

Viljoen, M. J., AND Viljoen, R. P. (1969a). The geology and geochemistry of the lower ultramafic unit of the Onverwacht Group and a proposed new class of igneous rocks. Geol. Soc. S. Afr. Spec. Pub. 2, 55-86.

Viljoen, M. J., AND Viljoen, R. P. (1969b). Evidence for the composition of the primitive mantle and its products of partial melting from a study of the mafic and ultramafic rocks of the Barberton Mountain land. Geol. Soc. S. Afr. Spec. Pub. 2, 275-295.

Viswanathan, S. (1974). Basaltic Komatiite occurrences in the Kolar gold field of India? Geol. Mag. 111, 353-354.

Walker, D., Stolper, E. M., and Hays, J. F. (1979). Basaltic volcanism: The importance of planet size. Lunar Planet. Sci. Conf. X, 12741276.

Wasson, J., AND Wetherill, G. (1979). Dynamical chemical and isotopic evidence regarding the formation locations of asteroids and meteorites. In Asteroids (Gehrels, Ed.). Univ. of Ariz. Press, Tucson.

Wetherill, G. W. (1974). Solar system sources of meteorites and large meteoroids. Annv. Rev. Earth Planet. Sci. 2, 303-332.

Williams, D. A. C. (1972). Archaean ultramafic, mafic and associated rocks, Mt. Monger, Western Australia.J. Geol. Soc. Aust. 19, 163-188. 